\title{
Formação econômica do espírito santo: do isolamento econômico à inserção aos mercados nacional e internacional
}

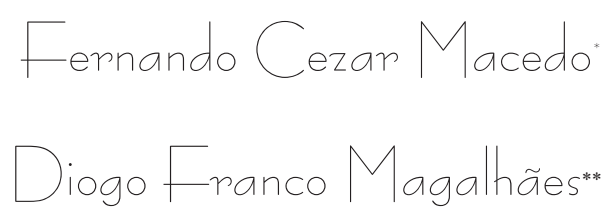

1. Apresentação

O objetivo deste texto é apresentar a formação e evolução econômica do estado do Espírito Santo, tomando como ponto de partida seu processo de conformação socioterritorial inicialmente derivado da cafeicultura, especialmente aquela que emerge com a pequena propriedade familiar e com a imigração estrangeira. Posteriormente, discute-se o advento do crescimento urbano-industrial a partir da década de 1960, quando o modelo anterior entra em crise.

Para atingir seu objetivo, o artigo encontra-se dividido em seis partes, além desta apresentação e das considerações finais. Na segunda, faz-se uma breve caracterização da região capixaba até a primeira metade do século XIX, fase que antecede o processo de imigração estrangeira. Em seguida, discute-se a importância da cafeicultura para sua ocupação territorial, com especial ênfase no papel da colonização e da

\footnotetext{
Professor do Insituto de Economia da UNICAMP, pesquisador do Centro de Estudos do Desenvolvimento Econômico (CEDE). Coordenador do Grupo de Estudos sobre Transformações Econômicas Regionais e Dinâmica Territorial. O autor agradece o apoio do CNPq. E-mail: fernando.cezar.macedo@gmail.com.

** Doutorando em História Econômica no Instituto de Economia da UNICAMP. E-mail: diogo.franco.magalhaes@gmail.com
} 
pequena propriedade rural. Na quarta, analisa-se a lógica de acumulação da cafeicultura no Espírito Santo, apontando seus limites e entraves para promover um processo de diversificação produtiva e um aprofundamento da urbanização. $\mathrm{Na}$ quinta parte é apresentado o projeto do governador $\mathrm{Mu}-$ niz Freire para centralizar a atividade comercial do café no município de Vitória, a partir dos investimentos portuários. Esse foi um momento importante, pois com a crise da cafeicultura capixaba nos anos 60 do século XX, analisada na sexta parte deste artigo, a capital do estado já estava equipada em função, também, dos investimentos da Companhia Vale do Rio Doce (CVRD), para comandar o processo de acumulação urbano-industrial que sucedeu a derrocada do café e a crise da agricultura capixaba. Este processo aumentou a inserção da economia espírito-santense nos mercados nacional e internacional, a partir de uma maior diversificação da estrutura produtiva, conforme se destaca na parte sétima que antecede as considerações finais.

\section{Caracterização da região capixaba até a primeira metade do século XIX}

O Espírito Santo é conhecido entre os estudiosos do período colonial como a região da "barreira verde", isto é, aquela em que o governo português restringiu, no início do século XVIII, o povoamento como medida frente ao contrabando de ouro e pedras preciosas das Minas Gerais, reforçando seu caráter litorâneo e não interiorizado. Outra medida da Metrópole que contribuiu para seu esvaziamento relativo fora a expulsão dos jesuitas dos domínios portugueses, em 1759. Como lembra Tallon, ${ }^{1}$ esses missionários constituíram aldeias em Retiba (Anchieta), Guaraparim (Guarapari), Serra, Reis Magos (Nova Almeida), além de fazendas em Itaoca, Araçatiba e Muribeca que produziam farinha de mandioca, açú-

${ }_{1}$ TALLON, M. D. História do Espirito Santo - ensaio sobre sua formação histórica e econômica. Vitória: IHGES, 1999. 
car e gado, contribuindo para a ocupação socioeconômica da região. No geral, contudo, a atuação jesuítica reproduziu o padrão litorâneo da cultura da cana-de-açúcar, introduzida no século XVI pelo donatário Vasco Fernandes Coutinho e que fora, até 1853, a principal atividade econômica da província.

Em verdade, tomado em seu conjunto, o movimento de colonização dos territórios que formariam o estado do Espírito Santo está articulado à lógica mais geral do "sentido da colonização" tal qual formulado por Caio Prado Jr. ${ }^{2}$ No entanto, sua especificidade reside em que se trata de uma região situada à margem dos principais centros produtores e praças comerciais do território brasileiro.

Assim, a historicidade do processo de ocupação desses territórios se dá sob uma série de limitações e oportunidades que se apresentam como "forças exteriores". A atividade canavieira surge como parte da empresa portuguesa em sua colônia na América do Sul, mas padece da concorrência de outros centros produtores no que diz respeito aos cabedais necessários aos investimentos iniciais. Frente à produtividade e ao nível de produção alcançados em outras capitanias, assim como ocorreu em outras áreas, a produção de cana-de-açúcar no Espírito Santo, apesar de rentável, não se transformou num ramo de atividade de grande expressão. No período subsequente, a mineração das Minas Gerais lançou o território numa situação de isolamento econômico e geográfico que prejudicou o processo de ocupação e povoamento. O episódio com os jesuítas é também inscrito no conjunto de determinações derivadas da relação entre metrópole e colônias, reforçando o quadro descrito.

Assim sendo, o período até a primeira metade do século XIX se apresenta em larga medida como uma afirmação

\footnotetext{
2 "No seu conjunto, e vista no plano mundial e internacional, a colonização dos trópicos toma o aspecto de uma vasta empresa comercial, mais completa que a antiga feitoria, mas sempre com o mesmo caráter que ela, destinada a explorar os recursos naturais de um território virgem em proveito do comércio europeu. É este o verdadeiro sentido da colonização tropical, de que o Brasil é uma das resultantes." PRADO JR., C. Formação do Brasil Contemporâneo: Colônia. São Paulo: Brasiliense, 1996, p. 31.
} 
da força das estruturas que dominavam a relação entre os territórios coloniais e Portugal, mas que, no caso do território do Espírito Santo, aparece sob o signo de um crescimento esparso, sem adensamento populacional ou comercial de maior vulto. Não se pretende afirmar que não havia alternativas de desenvolvimento histórico no período, mas que esses germes de outras configurações possiveis não lograram êxito nas condições estruturais apresentadas ao longo da época referida.

A essas restrições, acrescente-se outra de caráter geográfico: as dificuldades iniciais para transpor a região que fica ao norte do Rio Doce e que compreende cerca de $47 \%$ do atual território capixaba. As barreiras impostas pela floresta tropical, pela reação de grupos nativos - que apresentaram acirrada resistência à colonização dos brancos - e pelas doenças endêmicas como o impaludismo mantiveram essa região isolada. ${ }^{3}$ A exceção seria sua faixa litorânea, onde se destacava o núcleo de São Mateus que, elevado à categoria de vila em 1764, se tornara importante porto, com fortes ligações com a economia da Bahia.

As consequências dessas restrições - isolamento geográfico, estagnação demográfica e econômica - são amplamente documentadas pelos estudiosos preocupados com a história do desenvolvimento da região. ${ }^{4}$ Embora seja uma área de ocupação antiga, seu território manter-se-ia relativamente isolado e pouco povoado até metade do século XIX, quando a cultura do café definiria sua dinâmica por 100 anos a partir da imigração estrangeira - iniciada efetivamente em 1847 - e pela estrutura de pequenas propriedades que se organizou a partir dela, interiorizando seu povoamento.

Por essas razões, no início do século XIX a população do Espírito Santo não adentrara o continente, limitando-se

\footnotetext{
${ }^{3}$ BORGO, I.; PACHECO, R.; ROSA, L. B. R. de A. Norte do Espirito Santo: ciclo madeireiro e povoamento. Vitória: EDUFES, 1996.

${ }^{4}$ Uma síntese do assunto encontra-se em OLIVEIRA, J. História do Espirito Santo. Vitória: Fundação Cultural do Espírito Santo, 1975. Ver também: BITTENCOURT, G. Formação Econômica do Espirito Santo. Rio de Janeiro: Cátedra, 1987.
} 
a uma faixa litorânea que não excedia quatro léguas, como descrito por Saint-Hilaire. ${ }^{5}$ Distribuía-se por pequenas vilas ao longo da costa, sem grandes aglomerações urbanas e com densidade demográfica reduzida. Apesar da dispersão demográfica e da pequena população absoluta, observa-se (Tabela 1) que, em meados do século XIX, já se delineava uma configuração econômica e territorial regionalizada na província que perduraria até a segunda década do século XX, quando Vitória passou a exercer àquele momento - ainda que limitadamente - um poder de comando sobre a rede urbana estadual.

Tabela 1 - Distribuição da população da província do Espírito Santo, segundo localidade - 1856 e 1872

\begin{tabular}{lcccc}
\hline Localidade & $\mathbf{1 8 5 6}$ & $\mathbf{E m} \%$ & $\mathbf{1 8 7 2}$ & $\mathbf{E m} \%$ \\
\hline Região Central & $\mathbf{2 6 . 3 3 3}$ & $\mathbf{5 3 , 6}$ & $\mathbf{3 5 . 3 7 9}$ & $\mathbf{4 3 , 1}$ \\
Vitória & 5.002 & 10,2 & 4.361 & 5,3 \\
Espírito Santo & 1.311 & 2,7 & 1.755 & 2,1 \\
Viana & 3.502 & 7,1 & 6.547 & 8,0 \\
Cariacica & 4.122 & 8,4 & 5.318 & 6,5 \\
Mangarahi/Santa Leopoldina & 1.704 & 3,5 & 1.936 & 2,4 \\
Carapina & 1.330 & 2,7 & 1.157 & 1,4 \\
Serra & 2.524 & 5,1 & 4.294 & 5,2 \\
Queimado & 1.488 & 3,0 & 3.325 & 4,1 \\
Nova Almeida & 2.513 & 5,1 & 2.196 & 2,7 \\
Santa Cruz & 2.837 & 5,8 & 4.490 & 5,5 \\
Região de São Mateus & $\mathbf{6 . 8 1 7}$ & $\mathbf{1 3 , 9}$ & $\mathbf{1 0 . 0 3 3}$ & $\mathbf{1 2 , 2}$ \\
Linhares & 964 & 2,0 & 1863 & 2,3 \\
São Mateus & 3.602 & 7,3 & 4.657 & 5,7 \\
Barra de S Mateus & 2.251 & 4,6 & 3.513 & 4,3 \\
Região do Itapemirim & $\mathbf{1 5 . 9 4 2}$ & $\mathbf{3 2 , 5}$ & $\mathbf{3 6 . 6 6 5}$ & $\mathbf{4 4 , 7}$ \\
Benevente & 3.030 & 6,2 & 5.300 & 6,5
\end{tabular}

${ }^{5}$ SAINT-HILAIRE, A. Viagem ao Espirito Santo e Rio Doce. Belo Horizonte Itatiaia; São Paulo: EDUSP; Niteroi: EDUFF, 1974. 


\begin{tabular}{lcccc} 
Guarapari & 3.342 & 6,8 & 3.188 & 3,9 \\
Itapemirim & 5.520 & 11,2 & 9.681 & 11,8 \\
Itabapuana & 1.311 & 2,7 & 5.391 & 6,6 \\
Cachoeiro do Itapemirim & 2.739 & 5,6 & 13.105 & 16,0 \\
\hline Total da Provincia & $\mathbf{4 9 . 0 9 2}$ & $\mathbf{1 0 0 , 0}$ & $\mathbf{8 2 . 0 7 7}$ & $\mathbf{1 0 0 , 0}$ \\
\hline
\end{tabular}

Fonte: Ano de 1856, Relatório da Província do ES; ano de 1872, Recenseamento Geral do Brasil. Disponivel em:

<http:/ / biblioteca.ibge.gov.br/visualizacao/monografias / visualiza_colecao_digital.php?titulo=Recenseamento\%20Geral\%20 do\%20Brasi1\%201872\%20-\%20Imp\%C3\%A9rio\%20do\% 20 Brazil\&link=Imperio\%20do\%20Brazil\#>.

Um primeiro polo importante é a própria cidade de Vitória, cujo peso no total da população é flagrante em 1856, com perda de participação relativa em 1872 em decorrência do maior crescimento da produção cafeeira no sul do estado (região de Itapemirim). À capital se juntam outros núcleos da região central com alguma importância no total da população, como é o caso de Viana e Serra. Ao sul da província encontravam-se Itapemirim e Cachoeiro como mais importantes polos de concentração populacional. Destacava-se também Guarapari que, apesar da proximidade com a capital, foi agrupado na região de Itapemirim por estar atrelado à sua comarca no século XIX. O crescimento de Cachoeiro nesse período é um aspecto importante para a dinâmica socioterritorial, visto que o municipio sozinho foi responsável por metade do crescimento absoluto da população da região entre os dois anos indicados, resultado fundamentalmente do avanço de sua cafeicultura. Por fim, São Mateus e Barra de São Mateus se apresentam como núcleos de maior densidade no norte da província, embora suas participações relativas no total da população sejam inferiores aos dois polos supracitados. Como lembram Borgo, Pacheco e Rosa, ${ }^{6}$ essa região ficaria em posição passiva até metade do século XX, quando lhe chega o povoamento

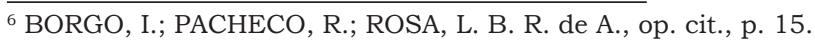


promovido pelo extrativismo madeireiro e pelo crescimento da agricultura (café, cacau e mandioca).

É importante registrar que a preocupação com o baixo povoamento é percebida como um grande problema a ser enfrentado. Nos documentos oficiais se encontram com frequência lamentos a respeito da falta de braços frente às "amplas oportunidades oferecidas pelas terras devolutas", conforme se observa na passagem a seguir:

[...] o meu pesar nasce da convicção de que a colonização estrangeira é o único meio de fazer prosperar com rapidez uma Província que encerrando tantos elementos de engrandecimento se conserva em estado de abatimento, e ocupa uma posição muito secundária entre as suas coirmãs por falta de população inteligente e ativa. Fertilíssimas e abundantes terras, importantes e numerosos rios que se cruzam em todos os sentidos aí estão unicamente para atestar a grandeza da Província em recursos naturais, e o seu atraso em civilização. ${ }^{7}$

A colonização por meio da imigração seria a solução indicada; solução interessante tanto do ponto de vista do povoamento quanto do fortalecimento do erário público, que poderia ganhar com a venda dos lotes rurais e aumento da arrecadação tributária, além da perspectiva de aumento da produção agrícola vinculada à ela que se refletiria, igualmente, nas contas públicas. Ademais, em relatório anterior era apontado que o avanço da colonização por meio da imigração ocorreria sem afetar interesses privados já constituídos, especialmente porque as terras estavam em mão do governo, havendo, portanto, condições suficientes para estimular esse alternativa que

[...] pode ser montada em terras de tamanha fertilidade, sem ferir a propriedade, nem mesmo a posse de pessoa alguma [...] Sobram-nos lugares onde assentar muitas colônias agrícolas. Aí estão essas riquíssimas e tão invejadas terras das antigas minas de Castelo. Aí estão as fertilíssimas e tão

\footnotetext{
${ }^{7}$ D’AZAMBUJA, J. B. Relatório da Província do Espirito Santo - 1952. Rio de Janeiro, Typographia Capitaneense T. A. de Azevedo, Vitória, 1852. Disponivel em: <wwwcrl.uchicago.edu/content/brazil/esp.htm>. Acesso em: 13 fev. 2007, p. 38-39.
} 
abandonadas gigantescas florestas que se estendem por um e outro lado do Rio Doce; aí estão as matas de Guarapari e de outros municípios da província, todos mais ou menos pertos dos portos e da navegação fluvial. ${ }^{8}$

Com baixa densidade demográfica que se estendia por grande parte de seu território e contando com apoio do governo imperial, foi possivel ocupar parcela dessas terras com o estabelecimento de quatro colônias oficiais: Santa Izabel (1847), Rio Novo (1855), ${ }^{9}$ Santa Leopoldina (1857) e Castelo (1880), além das colônias particulares (Quadro 1). Com a colonização estrangeira, inicia-se efetivamente um processo de ocupação sustentado por uma cultura - a do café - produzida dentro de uma estrutura específica - a pequena propriedade rural familiar -, o que possibilitou à região capixaba romper com seu relativo isolamento territorial, demográfico e econômico, integrando-se, ainda que muito fragilmente, aos circuitos mercantis da economia brasileira.

Quadro 1 - Colônias do Espírito Santo - Brasil (séculos XIX e XX) Fonte: Pacheco. ${ }^{10}$

\begin{tabular}{c|l|c|l|l}
\hline \multicolumn{1}{c|}{ Colônia } & \multicolumn{1}{|c|}{ Localização } & Ano & Predominância & Natureza \\
\hline Viana & $\begin{array}{l}\text { Margem rio Santo } \\
\text { Agostinho }\end{array}$ & 1813 & Açorianos & Oficial \\
\hline Santa Isabel & $\begin{array}{l}\text { Margem rio Jucu } \\
\text { (Estrada do Rubim) }\end{array}$ & 1847 & Alemães & Oficial \\
\hline Fransilvânia & $\begin{array}{l}\text { Margens rio Doce/ } \\
\text { Guandu }\end{array}$ & 1855 & - & Particular \\
\hline Rio Novo & Margem rio Novo & 1854 & Italianos & Particular \\
\hline
\end{tabular}

\footnotetext{
${ }^{8}$ Ferraz, L. P. do C. Relatório da Provincia do Espirito Santo - 1848. Rio de Janeiro, Typografphia do Diário N. S. Vianna, 1848. Disponivel em: <wwwcrl. uchicago.edu/content/brazil/esp.htm>. Acesso em: 13 fev. 2007, p. 28.

9 Fundada como empreendimento particular, esta colônia foi encampada em 1861 pelo governo imperial.

${ }^{10} \mathrm{PACHECO}, \mathrm{R}$. Os primeiros anos - Conflito nas colônias agrícolas espírito-santenses, 1827-1882. In: Estudos em homenagem a Ceciliano Abel de Almeida. Vitória: FCAA, 1978. Disponivel em: <http://www.estacaocapixaba.com.br/textos/historia/pacheco/colonias_agricolas_1.html>. Acesso em: 25 abr. 2007.
} 


\begin{tabular}{|c|c|c|c|c|}
\hline \multirow{3}{*}{$\begin{array}{l}\text { Santa } \\
\text { Leopoldina }\end{array}$} & $\begin{array}{l}1^{\circ} \text { núcleo: margem } \\
\text { Santa Maria }\end{array}$ & 1856 & Alemães & Oficial \\
\hline & $\begin{array}{l}2^{\circ} \text { núcleo: margem } \\
\text { Timbuí }\end{array}$ & - & Italianos & - \\
\hline & $\begin{array}{l}3^{\circ} \text { núcleo: margem } \\
\text { Piraquê-açu }\end{array}$ & - & Italianos & - \\
\hline Piúma & Margem Iconha & 1865 & Ingleses & Particular \\
\hline Juparanã & $\begin{array}{l}\text { Margens lagoa } \\
\text { Juparanã/rio Doce }\end{array}$ & 1867 & $\begin{array}{l}\text { Norte- } \\
\text { americanos }\end{array}$ & Particular \\
\hline Castelo & Margem rio Castelo & - & Italianos & Oficial \\
\hline $\begin{array}{l}\text { Santa } \\
\text { Leocádia }\end{array}$ & $\begin{array}{l}\text { Margem rio São } \\
\text { Mateus }\end{array}$ & 1887 & Italianos & Particular \\
\hline Muniz Freire & $\begin{array}{l}\text { Margem Santa Maria } \\
\text { do Rio Doce }\end{array}$ & 1895 & Italianos & Oficial \\
\hline Afonso Pena & $\begin{array}{l}\text { Margens rios } \\
\text { Guandu, Santa } \\
\text { Joana e Capim }\end{array}$ & 1907 & $\begin{array}{l}\text { Brasileiros e } \\
\text { alemães }\end{array}$ & Oficial \\
\hline $\begin{array}{l}\text { Antonio } \\
\text { Prado }\end{array}$ & Margem rio Doce & 1918 & Italianos & Oficial \\
\hline Acioli & Margem rio Doce & 1918 & Italianos & Oficial \\
\hline $\begin{array}{l}\text { Demétrio } \\
\text { Ribeiro }\end{array}$ & Margem rio Doce & 1918 & Italianos & Oficial \\
\hline $\begin{array}{l}\text { Águia } \\
\text { Branca }\end{array}$ & Margem rio São José & 1928 & Poloneses & Particular \\
\hline Serra & $\begin{array}{l}\text { Sopé do Mestre } \\
\text { Álvaro }\end{array}$ & 1964 & Sul-coreanos & Particular \\
\hline
\end{tabular}

\section{Cafeicultura e ocupação territorial do Espirito Santo ${ }^{11}$}

As primeiras notícias de café na província apontam, como área pioneira, o norte, no vale do Rio Doce, que teria exportado as primeiras sacas em $1812 .{ }^{12}$ No entanto, é com sua penetração na área meridional que ele ocuparia posição de destaque no desenvolvimento da Província. A expansão nela foi resultado da trajetória itinerante da cafeicultura mineira e fluminense em busca de novas terras, ${ }^{13}$ padecendo

${ }^{11}$ Baseado em MOTA, F. C. M., Integração e dinâmica regional: o caso capixaba (1960-2000). Campinas: IE/UNICAMP, Tese de Doutoramento, 2002.

12 OLIVEIRA, J. T., op. cit.

${ }^{13}$ Almada, V. P. F. de. A escravidão na História Econômica do Espírito Santo -1850/1888. Niterói: ICHF/UFF, Dissertação de Mestrado, 1981. 
de problemas em comum. ${ }^{14}$ No entanto, ainda que tenha se desenvolvido inicialmente em grandes fazendas, a forma predominante foi a pequena propriedade familiar que conviveu, durante algum tempo, com as fazendas escravistas. ${ }^{15}$ Os núcleos de colonização inicialmente e a decomposição das grandes fazendas do sul do estado (pós-Abolição) estimularam o aparecimento da pequena propriedade, permitindo, especialmente no primeiro caso, a ocupação da área central da Província.

Novamente, perpassa esse processo de implantação e crescimento da cafeicultura no Espírito Santo um sentido mais geral, derivado da dependência em relação às regiões centrais que configuravam a dinâmica da economia na época. Como dito, trata-se de um movimento derivado do esgotamento das áreas de expansão do café que repercute inclusive na transposição de seus arranjos produtivos - monocultura, escravidão, grande propriedade - para parte do território capixaba, principalmente a porção meridional que aparece como uma continuidade geográfica da região norte-fluminense.

No entanto, a especificidade do período - e que aparece com efeitos de maior duração para uma avaliação da história do Espírito Santo - reside na colonização de regiões no interior da província, sobretudo na região serrana, com o estabelecimento de imigrantes estrangeiros. O objetivo político de povoar a região e atrair mão de obra para fazer frente ao fim da escravidão propiciou uma configuração de propriedade da terra distinta, com pequenos proprietários e utilização de trabalho familiar, estrutura essa que ainda hoje é importante para a análise da região serrana do Espírito Santo.

Assim sendo, o desenvolvimento da cafeicultura no Espírito Santo a partir do século XIX responde a nexos com os

\footnotetext{
${ }^{14}$ Sobre diferentes padrões de cafeicultura ver CANO, W. Padrões Diferenciados das Principais Regiões Cafeeiras (1850-1930). In: Ensaios sobre a Formação Econômica Regional do Brasil. Campinas: UNICAMP/IE, 2002.

${ }^{15}$ É importante destacar que, apesar de ser cultivado em grandes fazendas, nelas a parte destinada ao café era pequena, o que indica uma baixa capacidade de produção.
}

70 Revista de História Regional 16(1): 61-99, Verão, 2011 
centros mais importantes da economia brasileira, mas em sua trajetória lançou as bases para o surgimento de uma estrutura com pequenas propriedades agrícolas, por meio da colonização estrangeira e da decadência e decomposição das grandes fazendas de café. Vejamos o impacto dos dois processos no ordenamento socioterritorial do Espírito Santo.

\subsection{Núcleos de colonização, imigração estrangeira e pequena propriedade}

A politica de imigração no Espírito Santo pode ser dividida em dois momentos que acreditamos não se contrapor à periodização feita por Rocha: ${ }^{16}$ o primeiro, de 1847-1887, corresponde à imigração orientada para a ocupação do território. O segundo, pós-Abolição, foi o de maior entrada de estrangeiros destinados a substituir nas fazendas de café a mão de obra liberta, mas não exclusivamente, visto que a política de colonização continuou. (Quadro 1).

Na primeira fase, observa-se nítido objetivo de colonização, que era vista como solução para reverter o quadro de estagnação da província. A forma de ocupação foi a pequena propriedade, estruturada economicamente em dois setores. Um, de subsistência, portanto não monetizado, que garantia seu provimento direto pela produção de alimentos e valores de uso para o dia a dia. ${ }^{17}$ Como descreveu um ex-presidente da Província, "a colheita chega para o consumo". ${ }^{18}$ Outro, gerador de divisas, articulava-se aos mercados nacional e

\footnotetext{
${ }_{16}$ ROCHA, G. Imigração estrangeira no Espirito Santo. Niterói: ICHF/UFF, Dissertação de Mestrado, 1984, p. 67-68.

${ }^{17}$ A ausência de um setor de alimentos forte, capaz de prover as necessidades da provincia, ajuda a entender o inexpressivo desenvolvimento dos núcleos urbanos até meados do século XX, resultado da baixa divisão social do trabalho decorrente do caráter autárquico das pequenas propriedades e de sua reduzida monetização.

18 PEREIRA JR., J. F. da C. Relatório da Provincia do Espírito Santo - 1862. Vitória, Typografphia Capitaniense de P. A. Azevedo, 1862, p. 98. Disponível em: <wwwcrl.uchicago.edu/content/brazil/esp.htm>. Acesso em: 13 fev. 2007.
} 
internacional por meio da produção do café, cuja comercialização era intermediada pelo capital mercantil sediado em Vitória ou, principalmente, na praça do Rio de Janeiro. Em ambos, a forma de trabalho predominante foi de natureza familiar ou marcada por outras relações de trabalho não assalariada.

É importante registrar que, em linhas gerais, o processo de imigração promovido pela cafeicultura paulista é substantivamente distinto daquele observado no Espírito Santo. No primeiro, o imigrante não teve o mesmo acesso à terra que no segundo e, para sobreviver, trabalhava para o fazendeiro seja de forma assalariada, seja em regime de colonato e/ou parceria. Embora pudesse plantar para além da subsistência, conseguindo minimamente formar excedentes passiveis de comercialização que lhes possibilitaram comprar terras, era visivel a subordinação aos fazendeiros a quem entregavam diretamente o produto de seu trabalho. No entanto, dado o assalariamento e a venda dos excedentes pelos imigrantes, houve um estímulo ao crescimento urbano que não se verificou alhures em mesma intensidade.

No segundo, ao contrário, dados os objetivos da colonização, o imigrante, além de proprietário da terra onde produzia, era dono do produto. Mesmo baixo, o excedente gerado na pequena propriedade familiar significava uma remuneração além da subsistência, apesar de apropriado em grande parte pela esfera da circulação. Talvez por isso $\mathrm{Pa}-$ checo $^{19}$ tenha escrito que os imigrantes no Espírito Santo tiveram "[...] niveis de vida superiores aos que usufruíam nos países de origem, desde o momento em que, como pequenos proprietários que eram, se voltaram, exclusivamente, para o cultivo do café". ${ }^{20}$

\footnotetext{
${ }^{19}$ PACHECO, R., op. cit.

${ }^{20}$ Campos Jr. também sugere que as condições dos imigrantes no Espírito Santo foram mais favoráveis do que a de seus pares paulistas. Ver: CAMPOS JR., C. T. Imigração Italiana e a Constituição da Pequena Propriedade no Espírito Santo. In: CASTIGLIONE, A. H.; BUSSATTO, L.; FAE, M ${ }^{\mathrm{a}}$ I.; PERINE, M ${ }^{\mathrm{a}} \mathrm{I}$. (Org.). Imigração Italiana no Espirito Santo: Uma Aventura Colonizadora.
}

72 Revista de História Regional 16(1): 61-99, Verão, 2011 
No entanto, não haveria, nesse regime de propriedade familiar, a possibilidade de concentração do excedente ${ }^{21}$ na órbita produtiva, tampouco alternativas de diversificações especialmente para atividades urbanas, como ocorrera em São Paulo, dada a fragilidade da produção ante o capital mercantil. Também contribuiria para isso a pulverização de capitais derivada da organização em pequenas propriedades, o precário sistema de transporte e o vazamento do excedente para outras praças - especialmente o Rio de Janeiro.

\subsection{Decomposição das grandes fazendas}

A principal área produtora de café a partir da segunda metade do século XIX foi a região de Itapemirim, que desenvolveu a cultura em grandes fazendas escravistas. A dificuldade em continuar a produção nos estabelecimentos no sul capixaba, com o advento da Abolição, desencadeou processo de desagregação das grandes propriedades, sendo este mais um vetor decisivo na organização socioespacial do Espírito Santo. Segundo Campos Jr.,

[...] após 1888 ocorreram inúmeros casos de fazendeiros que dividiram suas propriedades em lotes, passando a vendê-los aos imigrantes. Como forma de facilitar o empreendimento, tornando-o mais atrativo, o pagamento da terra era parcelado, e, quando o colono conseguia dinheiro para a prestação,

\footnotetext{
Vitória: EDUFES, 1998, p. 160-169. No entanto, essas afirmações devem ser, de fato, relativizadas. Relatos como aqueles apresentados na pesquisa de Renzo Grosselli e o relatório de Carlo Nagar de 1895 apontam as grandes dificuldades enfrentadas pelos imigrantes, especialmente pelos italianos. Ver: GROSSELLI, R. M. Colônias Imperiais na Terra do Café - Camponeses trentinos (vênetos e lombardos) nas florestas brasileiras - Espírito Santo 1874-1900. Vitória: Arquivo Público do Espírito Santo, 2008; NAGAR, C. O estado do Espirito Santo e a imigração italiana. Vitória: Arquivo Público do Espírito Santo, 1995.

${ }^{21}$ Além do fato de esse excedente ser quantitativamente menor do que o gerado em condições de produção capitalista.
} 
acertava-se o pagamento em quantidade equivalente de café. $^{22}$

Rapidamente, consolidaram-se empresas interessadas não apenas na venda dos lotes,${ }^{23}$ mas, sobretudo, na comercialização do café. Muitos fazendeiros tornaram-se comerciantes imobiliários. ${ }^{24} \mathrm{E}$ importante destacar que a operação de venda dos terrenos rurais estava diretamente ligada à comercialização da rubiácea na medida em que os colonos, ao adquirirem a propriedade, obrigavam-se a vender o produto à firma (ou ao comerciante) que transacionou o imóvel. Dessa maneira, o capital mercantil personificado na figura do comerciante ou das casas comerciais, graças à sua condição de comprador monopsônio da produção dos colonos sob sua abrangência, auferia ganhos tanto na venda dos lotes, quanto na compra do café oferecido como pagamento pela propriedade. Algumas firmas assentaram mais de 600 familias de imigrantes. ${ }^{25}$ Reforçava-se com isso a subordinação da produção ao comércio, pois,

[...] com a desagregação da grande propriedade e a formação da pequena, vai se abrindo espaço para o surgimento de firmas $[. .$.$] que, por seu intermédio, acabam concentrando a$ captura do excedente produtivo para a esfera da comercialização, ficando, de um lado, um imenso número de pequenos produtores e, de outro, uma cadeia extremamente articulada de casas comerciais controladoras de expressiva fração da comercialização do café capixaba. ${ }^{26}$

O fim da escravidão acelerou a desorganização dos cafeicultores sul-capixabas ao mesmo tempo em que a política oficial de imigração formava uma massa de trabalhadores que paulatinamente substituiria o trabalho escravo.

\footnotetext{
${ }^{22}$ CAMPOS JR. C. T. O Novo Arrabalde. Vitória: PMV/Secretária Municipal de Cultura e Turismo, 1985, p. 62.

${ }^{23}$ Sobre essa questão e a formação de pequenas propriedades, ver: SALETTO,

N. Transição para o trabalho livre e pequena propriedade no Espírito Santo (1888 - 1930). Vitória: EDUFES, 1996.

${ }^{24}$ CAMPOS JR., C. T., op. cit.

${ }^{25}$ Ibidem.

${ }^{26}$ Ibidem, p. 62.
} 
Imigrantes que ocuparam, também, áreas surgidas com o fracionamento das grandes propriedades, além de outras, devolutas, especialmente na região central. Embora desde 1813 haja esforços oficiais para atração de estrangeiros ao Espírito Santo, o estado receberia, efetivamente, uma grande leva de imigrantes na década de 90 do século XIX e que seria decisiva para sua ocupação e organização territorial, com adensamento e criação de núcleos populacionais (Quadro 1) - embriões de núcleos urbanos -, o que possibilitou a formação de uma incipiente rede estadual de cidades que se estruturaria a partir do café.

Do ponto de vista da política de imigração, dois resultados foram evidentes. O primeiro foi o próprio povoamento da região que, desde 1872 tomando por base os recenseamentos oficiais, passou a crescer demograficamente acima da média nacional (Tabela 2), não apenas em decorrência da montagem dos núcleos de colonização, mas, também, porque, até a década de 1940, o Espírito Santo tornou-se uma área de atração de imigrantes nacionais.

Tabela 2 - Brasil, regiões e estados selecionados - taxa média de crescimento anual da população, diversos períodos

\begin{tabular}{lllllllllllll}
\hline \multirow{2}{*}{ Periodo } & \multicolumn{8}{c}{ Taxas médias de crescimento anual da população (\%) } \\
\cline { 2 - 12 } & BR & NO & NE & SE & SUL & CO & ES & RJ & SP & PR & SC & RS \\
\hline 1872-1890 & 2,1 & 2,0 & 1,4 & 2,4 & 3,9 & 2,1 & 2,8 & 1,6 & 2,8 & 3,8 & 3,2 & 4,1 \\
$1890-1900$ & 2,0 & 3,9 & 1,2 & 2,5 & 2,3 & 1,5 & 4,4 & 2,2 & 5,1 & 2,7 & 1,2 & 2,5 \\
$1900-1920$ & 2,9 & 3,7 & 2,6 & 2,8 & 3,4 & 3,6 & 4,0 & 2,3 & 3,6 & 3,8 & 3,7 & 3,3 \\
$1920-1940$ & 1,5 & 0,6 & 1,3 & 1,5 & 2,4 & 1,8 & 2,8 & 1,4 & 2,3 & 3,0 & 2,9 & 2,1 \\
$1872-1940$ & 2,1 & 2,4 & 1,7 & 2,3 & 3,1 & 2,4 & 3,4 & 1,8 & 3,2 & 3,4 & 3,0 & 3,0 \\
\hline
\end{tabular}

Fonte: Censo Demográfico do IBGE. Vários anos.

Nota: $\mathrm{BR}=$ Brasil; $\mathrm{NO}=$ Região Norte; $\mathrm{NE}=$ Região Nordeste; $\mathrm{SE}=$ Região Sudeste; SUL = Região Sul; $\mathrm{CO}=$ Região Centro-Oeste. 
O segundo foi a conformação da estrutura fundiária decorrente tanto da política de imigração quanto da supressão do trabalho escravo, que levou ao fracionamento de fazendas cafeeiras cujos lotes foram vendidos aos imigrantes. Não por acaso, no Espírito Santo de 1920, 22,0\% do total da área de todas as propriedades rurais pertenciam a estrangeiros; uma proporção maior do que a verificada em outros estados que também receberam imigração europeia: Rio de Janeiro ${ }^{27}$ $(18,4 \%)$, São Paulo (16,3\%), Paraná $(12,8 \%)$, Rio Grande do Sul $(12,3 \%)$ e Santa Catarina (11,8\%). Da mesma forma, o censo de 1920 indica que para cada 4,4 estrangeiros residentes no estado havia uma propriedade rural que lhes pertencia, uma relação muito menor - portanto demonstrando maior acesso relativo à terra - do que a da maioria dos outros estados: Santa Catarina $(4,0)$, Rio Grande do Sul $(5,9)$, Paraná $(6,7)$, São Paulo $(37,6)$ e Rio de Janeiro $(84,2) \cdot{ }^{28}$ A estrutura de pequenas propriedades e o maior acesso relativo dos imigrantes à terra confeririam ao Espírito Santo e à Santa Catarina os menores indices de concentração fundiária ao longo de todo o século XX.

\section{Cafeicultura capixaba e sua dinâmica de acumulação}

Três importantes trabalhos, ${ }^{29}$ utilizando-se da metodologia desenvolvida por Cano, ${ }^{30}$ demonstraram que o café capixaba não conseguiu gestar as condições necessárias para a constituição de um complexo econômico capaz de assegurar o processo de desenvolvimento de formas de produção mais

\footnotetext{
${ }^{27}$ Para o Rio de Janeiro, agregamos o Rio de Janeiro e o Distrito Federal.

${ }^{28}$ Fonte: Recenseamento do Brasil - 1920. IBGE.

${ }^{29}$ ROCHA, H. C., COSSETI, $M^{a}$ da P. Dinâmica cafeeira e constituição da indústria no Espírito Santo - 1850/1930. Vitória: UFES/NEP/COPLAN/IJSN/ GERES, 1983; FERREIRA, S. P. Espírito Santo: dinâmica cafeeira e integração no mercado nacional 1840-1960. Rio de Janeiro: IE/UFRJ, Dissertação de Mestrado, 1987; Buffon, José A. O café e a urbanização no Espirito Santo: aspectos econômicos e demográficos de uma agricultura familiar. Campinas: IE/ UNICAMP, Dissertação de Mestrado, 1992.

${ }^{30}$ CANO, W. Raizes da concentração industrial em São Paulo. Campinas: IE/ UNICAMP, 1977.
} 
avançadas. A característica sob a qual esteve assentada a propriedade fundiária, em pequenos estabelecimentos, e as relações de produção presentes em seu interior, sobretudo após a transição para o trabalho livre (parceria e trabalho familiar, principalmente, portanto, baixo assalariamento da força de trabalho) explicam a dinâmica conferida à agricultura estadual e as dificuldades para desencadear, a partir de sua atividade central, um processo de diversificação da estrutura produtiva, como ocorrera em São Paulo, onde se constituiu um mercado assalariado na transição para o trabalho livre.

Dessa forma, embora o café constituísse o produto mais importante na geração da renda interna e da receita pública, não possibilitou a formação e a concentração de excedente no montante que garantisse a diversificação da economia capixaba. Tanto a grande dispersão da propriedade fundiária quanto a relativa pulverização do capital comercial contribuíram para a não constituição de mecanismos de centralização do excedente de sorte a permitir o salto da economia estadual, principalmente a formação de uma estrutura industrial e de serviços mais diversificada e menos dependente da cafeicultura. Ademais, era a praça do Rio de Janeiro que ficava com a maior parcela do que era gerado.

A dinâmica da economia cafeeira prevalecente até o final dos anos 1950 e início da década seguinte do século XX, quando a economia baseada na pequena produção familiar se esgota, pode ser representada em boa medida pelo comportamento secular dos pequenos produtores frente às crises periódicas pelas quais essa cultura passava. Como o café produzido representava uma espécie de renda extra, ou seja, uma parcela adicional à economia de subsistência, com a queda nos preços internacionais a produção se retraía e aumentava o trabalho na lavoura de subsistência, mantendo-se praticamente inalterada a estrutura de funcionamento da propriedade.

Dado o caráter eminentemente familiar das atividades e a predominância da força de trabalho não assalariada, não se formaram condições para redirecionamento dos 
fatores de produção para outras culturas, como em lavouras constituídas sob a lógica capitalista de produção, a exemplo do que se verificava nas regiões cafeeiras mais dinâmicas. Dessa maneira, sob as condições apontadas, não se constituiu agricultura mercantil alternativa ao café. Tampouco foi possivel àquela estrutura, inclusive por sua baixa monetização, desenvolver plenamente relações de produção que impulsionassem a formação de um mercado regional com maior segmentação e divisão do trabalho. Estabeleceu-se um círculo vicioso no qual o baixo dinamismo da cultura do café impediu a formação de excedentes que servissem de base à diversificação daquela estrutura e um salto para o desenvolvimento estadual - o que reforçava a baixa monetização e, por consequência, a estrutura vigente, não se constituindo elementos que intensificassem a divisão do trabalho de forma a gerar novas oportunidades de investimentos. À dispersão da propriedade rural juntavamse os limites do capital mercantil comercial, que, a despeito de ficar com a maior parte do rendimento monetário, subordinava apenas parcialmente os pequenos produtores, sem revolucionar, no entanto, sua base produtiva, visto que ele não tinha condições de impor plena sujeição à esfera produtiva. No limite, as decisões de produção cabiam ao produtor e não ao capital comercial, muito embora fosse este o elo mais forte da cadeia e o que ficava com a maior parte do excedente produzido. A passagem abaixo apresenta evidências da dificuldade encontrada pelo capital comercial em modernizar aquela base de acumulação, subordinando plenamente o produtor:

[...] por via de regra o pequeno lavrador está mais ou menos sob a tutela do comerciante para cuja casa transporta por obrigação a sua pequena colheita: o lavrador [...] é muita vez indiferente ao progresso do seu estabelecimento; satisfaz-se com pequenas vantagens que já se habituou a tirar dos processos imperfeitos e rotineiros de que usa. A fraqueza da lavoura vai refletir diretamente em prejuízo dos grandes interesses do comércio da província que mesmo na capital está 
muito longe de ser o que se poderia almejar adstrito ao Rio de Janeiro. ${ }^{31}$

Portanto, observava-se uma dissociação clara entre a produção e a realização, que, embora sejam teórica e logicamente distintas, são, no modo de produção capitalista, partes indissociáveis do mesmo circuito de valorização do capital. Esse não se unificava em torno de um capital que exercesse força hegemônica sobre a estrutura produtiva, subordinando as relações de produção a suas necessidades de valorização: aqueles dois momentos (produção e realização) não eram unificados através da figura do comerciante, tampouco na do produtor. Nem o excedente produzido permitiu a formação e a apropriação de um montante que lhes possibilitasse diversificação para outras atividades (comércio, bancos, serviços e indústria), nem o capital comercial conseguiu exercer controle sobre as decisões de produzir nas pequenas propriedades, subordinando-as formalmente à órbita da circulação, revolucionando sua base produtiva como forma de alcançar ganhos de produtividade que permitissem a formação de maior excedente da principal mercadoria comercializável (ou mesmo a diversificação da lavoura) e sua canalização para atividades alternativas. Mais que isso, nos momentos de crise as condições de produção não eram alteradas significativamente, a ponto de permitir ao capital comercial uma mercadoria alternativa que possibilitasse ganhos na esfera da circulação. Não se gerou estímulo, portanto, para o aprofundamento da divisão social do trabalho.

Em última instância, era o proprietário quem decidia sobre a produção, embora não tivesse qualquer influência sobre sua realização; ao contrário, encontrava-se relativamente fragilizado frente à figura do comerciante. Como era o preço internacional do café que ditava o ritmo da acumulação, em momentos de crise, dada a estrutura produtiva "autárquica" da pequena propriedade, era bastante remota a possibilidade de redirecionamento da produção para outras

${ }^{31}$ CORREA, F. F. Relatório da Provincia do Espirito Santo - 1871. Vitória, Typographia do Correio de Victoria, 1872, p. 110. Disponivel em: <wwwcrl. uchicago.edu/content/brazil/esp.htm>. Acesso em: 13 fev. 2007. 
lavouras de exportação, a despeito da necessidade de um produto alternativo que garantisse a rentabilidade do capital mercantil, sobretudo em períodos de incerteza crescente.

Dessa forma, nos momentos de crise, rompiam-se os circuitos de valorização do capital, como, aliás, se verifica em todas as atividades e setores movidos pelo lucro. Porém, na agricultura capixaba, diferentemente do que se observava em regiões que apresentavam relações capitalistas mais desenvolvidas, a reconstituição desse circuito ficava obliterada pelas características de sua estrutura produtiva e pela ausência de um capital comercial capaz de transformar as relações de produção de sorte a reconstituir os circuitos de valorização em patamar mais elevado, tanto do ponto de vista técnico-produtivo, quanto dos crescentes níveis de acumulação e diversificação das atividades.

A citação seguinte, tirada de uma mensagem do presidente do estado, confirma essa situação, apesar de seu autor ver, naquela estrutura, uma vantagem sobre outras baseadas em relações capitalistas:

É uma vantagem para o estado, não há dúvida, a sua pequena lavoura; ela resiste mais que a outra, porque não têm dependência e basta-se a si própria. As crises como a atual podem matar-lhe os estímulos, cercar-lhe a vida de sacrificios e penas, mas enquanto o trabalho garante o pão quotidiano, ela pode renunciar por longo tempo a outras ambições, e não desampara o campo regado pelos seus suores. ${ }^{32}$

Em sintese, não haveria alternativas para a diversificação produtiva a partir da pequena propriedade familiar que, objetivamente, jamais contou com políticas públicas e instrumentos de apoio. Como o café constituía a produção mais rentável, mesmo em crise, sua cultura continuava a ser a principal de natureza mercantil-exportadora, portanto, aquela passivel de gerar alguma monetização através da for-

\footnotetext{
${ }^{32}$ FREIRE, J. M. C. M.. Mensagem ao Congresso Legislativo. Vitória, Papelaria e Typographia Nelson Costa, 1903, Disponivel em: <wwwcrl.uchicago.edu/ content/brazil/esp.htm>. Acesso em: 13 fev. 2007.
} 
mação de excedentes comercializáveis. Isso reforçava o baixo dinamismo da produção, na medida em que não se gestavam alternativas para a dependência crescente desse produto, criando um círculo vicioso que não poderia ser rompido dentro da estrutura vigente com baixo nivel de assalariamento e técnicas mais atrasadas de produção. Ademais, inexoravelmente, a ocupação territorial, o esgotamento da fronteira agrícola interna e o fracionamento dessas propriedades entre os herdeiros levariam aquela estrutura ao estrangulamento, como se observou nos anos 1940 e 1950, quando o Espírito Santo tornou-se, depois de mais de um século, uma região expulsora de contingentes populacionais, uma vez que não dispunha, como antes, do amortecedor social possibilitado pelo avanço da fronteira fundiária interna.

A dinâmica da agricultura familiar esbarraria, portanto, em seus limites internos, com o esgotamento dos fatores que a impulsionavam - fartura de terras e atração populacional -, levando-a a uma crise que, segundo Buffon, ${ }^{33}$ seria inevitável a despeito da crise provocada pelos preços internacionais do café na segunda metade da década de 1950 e que apenas acelerou o fim do modelo vigente, o que culminaria com as mudanças estruturais significativas pelas quais passaria a economia estadual a partir de então.

Nesse sentido, o Espírito Santo, a exemplo do Brasil até as primeiras décadas do século $\mathrm{XX}$, desenvolveu uma economia primário-exportadora cuja variável determinante de crescimento estava dada pelas exportações de seu principal produto, ou seja, a dinâmica desta economia e os aumentos da renda advindos de sua atividade nuclear estavam exogenamente determinados pela variação dos preços do café no mercado internacional. ${ }^{34}$ No entanto, dado o caráter de produtor marginal, nem mesmo indiretamente, através

\footnotetext{
${ }^{33}$ BUFFON, J. A. O café e a urbanização no Espirito Santo: aspectos econômicos e demográficos de uma agricultura familiar. Campinas: IE/UNICAMP, Dissertação de Mestrado, 1992.

${ }^{34}$ Não adotamos aqui um conceito radical de exógeno. Nem todas as atitudes econômicas, na dinâmica de acumulação, foram decorrentes de ações ou efeitos externos.
} 
do controle da oferta, o Espírito Santo poderia interferir no preço de seu principal produto, ficando entregue à própria sorte, ou pior, às flutuações do preço do café no mercado internacional. Ademais, a estrutura produtiva não permitia uma capitalização sustentada dessa agricultura, inviabilizando a formação de excedente que pudesse ser transferivel para outras atividades mais dinâmicas. Tampouco fomentou urbanização geradora de externalidades que pudessem estimular atividades secundárias e terciárias de maior vulto. As palavras de Cano resumem bem a questão:

Como se vê, também no Espírito Santo, a transição não fez surgir uma economia de base assalariada. Sua dependência até meados da década de 1920, do Porto do Rio de Janeiro e sua mantida subordinação ao capital mercantil sediado fora também ajudaram a impedir a constituição de um verdadeiro complexo cafeeiro [...] [Ademais] a expansão dera-se, basicamente, no campo, gerando escassa e dispersa urbanização. Certamente, esse fato, além da problemática de sua economia cafeeira, não propiciou a gestação de vínculos que possibilitassem a expansão de mercados estimuladores de uma diversificação agrícola e industrial. ${ }^{35}$

Se não gerou estímulos para "uma diversificação agrícola e industrial", e apesar de a economia cafeeira não ter fomentado as condições para o aprofundamento da divisão social do trabalho, foi ela o principal vetor de crescimento da economia do Espírito Santo e seu mais importante elemento de organização territorial até meados do século XX, contribuindo para a construção da base material e o desenho espacial sobre o qual se daria a diversificação promovida pelo crescimento da indústria e dos serviços a partir da década de 1960 , quando se criaram alternativas para superar a dependência secular do café.

Note-se, portanto, que o sentido da colonização surge de maneira concreta na organização socioespacial da economia sob a égide do capital mercantil, que articula os setores agrícolas em formação ao redor da economia cafeeira. Toda-

${ }^{35}$ CANO, W., op. cit, 2002, p. 61-62. 
via, o desenvolvimento da própria economia cafeeira carregou em germe as possibilidades de mudanças qualitativas na economia do Espírito Santo. Para compreendê-las, no entanto, é preciso indicar como a cidade de Vitória tornar-se-ia o lócus do crescimento urbano-industrial que emergiria na segunda metade dos anos 1960 em substituição à cafeicultura como principal vetor de organização socioeconômica e territorial do estado a partir de então.

\section{Governos Muniz Freire e a construção da infraestru- tura em Vitória}

Como lembra Tallon, ${ }^{36}$ no primeiro governo Muniz Frei$\mathrm{re}^{37}$ há uma nítida preocupação com a melhoria dos sistemas de transportes, ${ }^{38}$ destacando-se o início da construção da estrada de ferro do Sul do Espírito Santo que teve o trecho entre Argolas e Viana inaugurado em 1895. A conclusão da estrada - depois chamada de Leopoldina-ocorreu em 1910, possibilitando o escoamento de parte da produção da região Sul para Vitória, esvaziando relativamente o porto de Itapemirim e diminuindo a dependência em relação à praça fluminense. Esta estrada juntou-se a outra - a estrada de ferro Caravelas - que funcionava desde 1887, em trecho de $50 \mathrm{~km}$ ligando Cachoeiro de Itapemirim à estação de Pombal e com um ramal de $21 \mathrm{~km}$ ligando Matosinho a Castelo, no sul do Espírito Santo, conforme lembra Oliveira. ${ }^{39}$

A cidade de Vitória já centralizava o café produzido na área de ocupação imigrante e teria, ao longo do século XX, papel importante na centralização das atividades econômicas

\footnotetext{
${ }^{36}$ TALLON, M. D. op. cit, 1999.

${ }^{37}$ José de Melo Carvalho Muniz Freire foi presidente do estado do Espírito Santo por dois mandatos, entre 1892 e 1896 e entre 1900 a 1904.

${ }^{38}$ Destaca-se, também, a entrada de 20 mil imigrantes promovida pelo governo de Muniz Freire.

${ }^{39}$ OLIVEIRA, J. T., op. cit, p. 395.
} 
do estado, com investimentos feitos em sua urbanização e, sobretudo, em seu porto. É por essa razão que o crescimento industrial que emerge como resposta à crise na cafeicultura na década de 1960 concentrar-se-ia na capital e em seu entorno imediato, única área com condições infraestruturais para atender a exigências atreladas à lógica de crescimento urbano-industrial que se processava no momento, articulando a base de produção do estado às economias nacional e internacional.

Campos Jr. ${ }^{40}$ também aponta o governo de Muniz Freire, principalmente o primeiro, quando as condições de preço do café lhe foram favoráveis, como marco na concepção do papel que a cidade de Vitória poderia ter sobre a economia do Espírito Santo. O plano de Muniz Freire consistia em centralizar o comércio do café capixaba e parte do de Minas Gerais em Vitória, o que determinaria uma função de especial importância a essa cidade, além de permitir um processo de urbanização da capital. Na década de 1920, Vitória, com a ampliação dos serviços portuários e com os serviços de exportação e importação, iria consolidar sua posição de principal lócus comercial do Estado através de seu porto. ${ }^{41}$

Se inicialmente a dinâmica estava atrelada à comercialização do café, posteriormente a cidade incorporaria novos serviços e novas modalidades de inserção na economia nacional/internacional, possivveis graças ao investimento portuário. O marco que possibilitaria uma futura diversificação foi o início das operações da CVRD em 1942, que passaria a atuar diretamente no território capixaba, alternando-lhe as bases de organização Segundo Buffon et al.,

[...] apesar da sua proeminência no quadro urbano estadual, somente nos anos cinqüenta é que Vitória passa a ser a mais importante cidade do Estado, tendência que prossegue em franco desenvolvimento nos dias de hoje [...] [No entanto,] até

${ }^{40}$ CAMPOS JR., C. T., op. cit., 1996.

${ }^{41}$ Sobre o porto de Vitória, consultar: SIQUEIRA, M. P. S. O desenvolvimento do porto de Vitória - 1870-1940. Vitória: CODESA, 1995; SIQUEIRA, M. P. S. O porto de Vitória: expansão e modernização - 1950-1993. Vitória: CODESA, 1994. 
1940, a cidade de Vitória é o centro comercial e de serviços de uma região cafeeira e está subordinada fundamentalmente à lógica da produção material que se origina no campo: ou seja, a cidade é exclusivamente rural, cafeeira e capixaba. De 1942 a 1966 abre-se um período de transição, em que às demandas cafeeiras, inclusive já em transformação, somam-se demandas provenientes das atividades da CVRD em solo capixaba, as quais em última análise, se referem à produção material que se realiza em território de Minas Gerais. A partir de 1966, até o final dos anos oitenta, completa-se o período de transição: a cidade perde completamente seus aspectos cafeeiros e deixa de ser uma cidade exclusivamente capixaba. O porto de Tubarão permitiu um colossal desenvolvimento de certas demandas produtivas que já se projetavam sobre a cidade, quais sejam, as atividades portuárias relacionadas com a produção material realizada em Minas Gerais. Permitiu, da mesma forma, a instalação de indústrias no Espírito Santo, que foram projetadas sob a lógica de localização gerada pelo complexo ferro-portuário, com destaque para a CST e as usinas de pelotização da CVRD. Ao final dos anos oitenta está consolidada em definitivo a transição urbana da cidade. Ainda que continue como antes, sendo fundamentalmente exportadora, sua lógica de funcionamento é dada pela base industrial. ${ }^{42}$

Quando a região Norte, última de expansão da fronteira interna, torna-se área pioneira e dominante da cafeicultura capixaba na década de 1920, capitaneada pelo município de Colatina, a cidade de Vitória já havia capturado o mercado regional, passando a exercer o comando sobre a rede urbana capixaba, ainda que isso só se tornasse mais evidente a partir dos anos 50 e especialmente 60 do século XX, quando o início das operações do porto de Tubarão (1966) lhe ampliou significativamente as funções terciárias, aumentando sua centralidade para além do território capixaba e superando, definitivamente, os limites da estreita base de acumulação da cafeicultura estadual como principal elemento de ordenação socioterritorial do estado.

\footnotetext{
${ }^{42}$ Buffon, J. A. et al. Uso e Ocupação do Solo Urbano. Vitória: CDV/Projeto Vitória do Futuro, mimeo, 1996, p. 8-9.
} 


\section{Crise na agricultura, transição para uma base de acumulação urbano-industrial e a herança do café}

Conforme demonstramos na seção 4, a estrutura da cafeicultura capixaba apresentou dificuldades especificas para desenvolver relações de produção avançadas que possibilitassem a diversificação produtiva. Em decorrência disso, e apesar das transformações ao longo da primeira metade do século XX, especialmente o fortalecimento da centralidade de Vitória sobre a rede urbana estadual, não parece exagero afirmar que a dinâmica de sua cafeicultura apresentava uma relativa estabilidade.

Dependente da oferta elástica de terras, especialmente pelo processo extensivo de produção sem incorporação de progresso técnico que provocou o empobrecimento dos solos, a agricultura no estado esbarraria em seus limites internos, sobretudo o esgotamento da fronteira agrícola. Inexoravelmente, ao ser deixada à sorte do mercado, aquela estrutura trazia internamente o germe de sua crise, que seria inevitável nas condições vigentes, a despeito da crise provocada pela queda dos preços internacionais do café na segunda metade da década de 1950 - e que resultou na política federal de erradicação dos cafezais na década seguinte. Esta desorganizou a agricultura no Espírito Santo, mas tornou-se um ponto de inflexão na substituição da base produtiva primário-exportadora assentada no café para outra, de caráter urbano-industrial, que resultaria, nas últimas quatro décadas, na transformação da região em um espaço econômico mais diversificado.

É importante ressaltar, portanto, que na década de 50 do século XX o modelo de pequenas propriedades já demonstrava dificuldade de prosseguir em sua base secular de acumulação, à medida que a fronteira interna no norte do estado era paulatinamente ocupada - inclusive com maior concentração fundiária - e não se observava alteração na composição orgânica do pequeno capital de forma a elevar a produtividade agrícola compensando, assim, a falta de elasticidade 
da oferta de terras. Conforme já destacado, uma evidência desse limite poderia ser encontrada na reversão dos saldos migratórios no Espírito Santo. Após 100 anos de entrada líquida de população - tanto de imigrantes estrangeiros quanto nacionais - o estado tornou-se, pela primeira vez, uma região expulsora, indicando que a crise daquela estrutura estava internamente potencializada antes mesmo da queda dos preços internacionais do café no final dos anos 1950, que provocou a erradicação dos pés na década de 1960, gerando grave crise social.

A crise, no entanto, afetou de forma desigual a região capixaba. As mudanças em sua estrutura produtiva provocadas pela decadência da cafeicultura tradicional desencadearam simultaneamente processo de esvaziamento relativo do interior do estado, que apresentou perda de população com a erradicação dos cafezais nos anos 1960, ao mesmo tempo em que se observava crescente urbanização da capital e de seu entorno, que foram as principais áreas beneficiadas pelas politicas de combate à crise da agricultura estadual, além de investimentos decorrentes do Plano de Metas. Ademais, a cidade de Vitória já apresentava, desde a intervenção de Muniz Freire e de seus sucessores, melhor infraestrutura - especialmente portuária - que lhe assegurou a condição de principal área para investimentos no estado.

A crise na agricultura tradicional e os estímulos ao investimento industrial derivados da ação do setor público (federal e estadual), através da montagem de um sistema de incentivos fiscais e da atração de grandes plantas industriais voltadas para atendimento do mercado externo, possibilitaram a diversificação produtiva no Espírito Santo - ainda que limitada - que, por se concentrar na RMGV, ${ }^{43}$ aumentou a centralidade da capital que passaria a ser o principal elo entre a estrutura produtiva emergente no Espírito Santo e as economias nacional e internacional. Nesse sentido, a crise da agricultura representou também o momento da efetiva integração da economia capixaba à economia brasileira,

43 Região Metropolitana da Grande Vitória, atualmente constituída pelos municipios de Vitória, Vila Velha, Serra, Cariacica, Viana, Fundão e Guarapari. 
conforme demonstrou Mota, ${ }^{44}$ além de maior fortalecimento de seus laços com a economia internacional, agora não mais exclusivamente com café, mas, principalmente, com as exportações de produtos semielaborados de indústrias que se localizariam no estado, atraídas pelas boas condições de infraestrutura derivadas das ações da CVRD no território capixaba e pelos estímulos das políticas federais.

Poderíamos citar, sem pretensões de hierarquizá-los, os principais vetores das transformações produtivas da economia capixaba nas últimas quatro décadas que lhe possibilitaram sair de seu isolamento relativo e integrar-se produtivamente nas economias nacional e internacional: (I) a crise na produção do café, consequência da queda do seu preço internacional, mas principalmente dos limites internos da cafeicultura tradicional no estado; (II) politica industrial, com intervenção do Governo Federal, no sentido de incentivar especialmente os setores básicos que se localizaram no Espírito Santo; (III) a construção de infraestrutura com características específicas, atraindo iniciativas industriais para o Estado; (IV) transbordamento da economia brasileira, que a partir do Plano de metas encontraria na periferia alternativas para expansão; (V) a montagem do sistema estadual de incentivos fiscais e financeiros para atração de investimento; (VI) a expansão do mercado consumidor urbano no Espírito Santo; (VII) o esgotamento da estrutura de produção familiar na cultura cafeeira; (VIII) a politica nacional de erradicação dos cafezais na década de 1960; (IX) a construção de uma institucionalidade estadual que permitiria a implementação de políticas de apoio à indústria. Todos esses vetores agiram no sentido de aumentar, direta ou indiretamente, a concentração na RMGV.

É importante registrar, no entanto, que, apesar de a economia cafeeira no estado do Espírito Santo não ter fomentado as condições para que ele participasse mais ativamente do desenvolvimento verificado na economia brasileira sob a liderança da industrialização paulista, e a despeito de não

${ }^{44}$ MOTA, F. C. M., op. cit. 
ter conseguido diversificar a estrutura produtiva estadual, foi o café que polarizou os principais investimentos na agricultura no período anterior a 1960: organizou o mercado de trabalho, sendo inclusive o principal responsável pela ocupação da mão de obra; exerceu importante influência na formação da incipiente indústria estadual; expandiu a fronteira agrícola, promovendo a interiorização do estado e a ocupação do solo, alterando sensivelmente a composição espacial capixaba. Quanto a este último aspecto, é nítido que o avanço da fronteira agrícola, desde a segunda metade do século XIX, vai acompanhando o traçado das novas propriedades cafeeiras, seguindo o tradicional roteiro mata-café-pastagem, como apontam alguns dos trabalhos citados ao longo do texto, até o momento em que se verifica praticamente toda a ocupação do solo capixaba na década de 1960.

Vale ressaltar, ainda, que o café, além de ser o principal responsável pelo crescimento da economia espírito-santense até os anos 1960, determinou, também, a dinâmica das atividades secundárias e terciárias à medida que seu beneficiamento e sua comercialização geravam incrementos de renda tanto na pequena (e insignificante até então) estrutura industrial do estado quanto no setor de comércio e de serviços, especialmente aqueles localizados em Vitória.

Portanto, embora a atividade cafeeira não tenha constituído uma economia primário-exportadora dinâmica - e tampouco tenha fomentado a divisão social do trabalho de forma a criar uma diferenciação na economia que possibilitasse a expansão do mercado interno capixaba e de sua integração ao mercado nacional -, legou duas importantes contribuições: a constituição de núcleos urbanos pelo interior e a consolidação de Vitória como a principal e a mais importante cidade da região capixaba, provedora de importantes serviços de apoio à atividade cafeeira estadual. Entre esses serviços, destacam-se aqueles ligados à comercialização, em especial o desenvolvimento da atividade portuária, que fomentou uma série de vantagens aglomerativas que a transformaram - juntamente com seu entorno imediato - no lócus principal do crescimento 
capixaba, quando este se processa de forma mais intensiva, ao final dos anos 1960, superando os limites da tradicional cafeicultura no processo de diversificação da economia local.

\section{Acumulação urbano-industrial e diversificação produtiva: do isolamento econômico à inserção nos mercados nacional e internacional}

Em boa medida, antes mesmo da crise na cafeicultura, já havia a percepção de que seria necessário um reordenamento econômico, político e institucional para dinamizar a base produtiva, sob pena de o estado aumentar seu atraso relativo frente às economias mais desenvolvidas do país que cresciam a taxas elevadas puxadas pela industrialização. Esse sentimento era fortalecido principalmente pela evidência de que o predomínio do café sobre a geração da renda e da receita estaduais impunha limites ao desenvolvimento capixaba e à possibilidade de diversificação de sua economia. Com a crise em sua cafeicultura e com o programa federal de erradicação dos cafezais ampliaram-se as reinvindicações por alternativas que evitassem a estagnação ou mesmo o retrocesso econômico.

A erradicação dos cafezais praticada pelo Governo Federal como medida de ajuste da oferta, apesar da grave crise social que resultou em cerca de 60 mil trabalhadores desempregados no Espírito Santo, atuou no sentido de desmobilizar os ativos representados nos cafeeiros, aumentando a liquidez de sua economia e, por consequência, as oportunidades de investimentos em atividades alternativas, como a pecuária e a indústria madeireira, sendo que ambas, aliás, assumiram importância crescente no estado na década de $1960 .{ }^{45}$ Esse momento determinaria um ponto de inflexão no desenvolvimento da economia capixaba e o início de um processo de diversificação de sua estrutura e de maior integração à economia brasileira, ainda que a passos tímidos.

\footnotetext{
${ }^{45}$ MORANDI, A.; ROCHA, H. C. Cafeicultura e grande indústria: a transição no Espirito Santo 1955-1985. Vitória: FCAA, 1991.
}

90 Revista de História Regional 16(1): 61-99, Verão, 2011 
Além dos efeitos da erradicação, outro fato mobilizaria os atores estaduais em busca da diversificação produtiva. Trata-se da criação da SUDENE em 1960. Como o Nordeste foi considerado prioritário na questão regional brasileira, o estado do Espírito Santo ficaria inicialmente à margem da política de incentivos do Governo Federal, a despeito de seus péssimos indicadores socioeconômicos que, à época, o equiparavam aos apresentados pelo GTDN. ${ }^{46}$ Esse fato provocou um movimento reinvindicatório de inclusão do estado na política regional brasileira. Isso acirrou a defesa da industrialização como forma de alavancagem, o que levou um grupo de empresários ligados à Federação do Comércio a montar, em 1958, a FINDES (Federação das Indústrias do Espírito Santo) que teria papel decisivo na montagem da estrutura de apoio à indústria constituída no governo de Christiano Dias Lopes Filho (1967-1971).

O ambiente em favor de uma política industrial estava formado e foi, em boa medida, favorecido pelo fato de que as politicas regionais ainda encontravam espaço e apoio suficientes para serem implementadas pelos governos subnacionais. Nesse interim, foi possivel durante o governo Dias Lopes articular os interesses locais emergentes às políticas federais. Naquele contexto, o grupo de interesse que começava a se articular mais sistematicamente a partir da criação da FINDES consegue impor seu projeto político no estado com apoio do Governo Federal a ponto de afastar, via articulação na Assembleia Legislativa, o governador Francisco Lacerda de Aguiar - o Chiquinho ${ }^{47}$-, ligado aos interesses da agricultura, acusado de corrupção e de apoio "aos comunistas", mesmo tendo defendido o golpe militar de 1964. Basta mencionar que o então deputado estadual

\footnotetext{
${ }^{46}$ Grupo de Trabalho para o Desenvolvimento do Nordeste, coordenado pelo economista Celso Furtado, cujo relatório-sintese serviu de base para a criação da SUDENE. Sobre este assunto, ver: FURTADO, C. A construção interrompida. São Paulo: Paz e Terra, 2000.

${ }^{47}$ Chiquinho foi governador por dois mandados: 1952-1955 e 1963-1966.
} 
e futuro governador Christiano Dias Lopes Filho foi o "comandante da ação anti-Chiquinho". ${ }^{48}$

Do aparato institucional criado, destaca-se o Fundo de Recuperação Econômica do Estado do Espírito Santo (FUNRES). Esse foi o principal resultado das articulações que levaram à criação do Grupo Executivo de Recuperação Econômica do Espírito Santo (GERES) ${ }^{49}$ para coordenar, articulado ao Banco de Desenvolvimento do Estado do Espírito Santo (BANDES), uma política industrial. Ressalte-se, ainda, que o FUNRES particularizou o Espírito Santo como o único estado brasileiro a dispor de um instrumento de desenvolvimento regional instituído pelo Governo Federal como forma de compensar o declínio de sua cafeicultura. Os demais fundos similares (FINOR ${ }^{50}$ - Fundo de Investimentos do Nordeste e FINAM - Fundo de Investimento da Amazônia) estavam voltados para o desenvolvimento de um conjunto de estados formadores de uma mesma macrorregião.

Além da constituição do sistema estadual de desenvolvimento na década de 1960, o estado veria na década seguinte a atração de grandes plantas industriais, principalmente uma usina siderúrgica - velha demanda dos politicos capixabas -, pelo aproveitamento das vantagens locacionais derivadas da presença do Porto de Vitória e da CVRD. Essa empresa diversificou suas atividades no estado com a construção

${ }^{48}$ Conforme noticiava o jornal $O$ Diário na época. Sobre o assunto, ver: Chico, Chiquim, Chiquinho. Jornal Século Diário. Disponível em: http://www. seculodiario.com/reportagens/index_chico02.htm. Acesso em 28 jan. 2011.

49 Órgão colegiado, vinculado por coordenação ao Ministério da Integração Nacional, composto por 11 (onze) membros, sendo 7 (sete) representantes do Governo Federal e 4 (quatro) representantes do Governo Estadual, tem por finalidade administrar e disciplinar o uso dos recursos do FUNRES - Fundo de Recuperação Econômica do Estado do Espírito Santo. Disponivel em: <http:// www.geres.gov.br/colegiado_atribuicoes.php >. Acesso em 28 jan. 2011.

${ }^{50}$ Em 1998, 27 municípios do norte capixaba passaram a integrar a área de influência da SUDENE, portanto, passiveis de utilização dos recursos FINOR. Embora venha a atender uma velha reivindicação dos politicos capixabas, a entrada de parte do estado na SUDENE resulta da falta de uma política regional do Governo Federal, que há muito já não estabelece linhas de prioridades e de ação seletiva nessa área. Paradoxalmente, quando os indicadores capixabas estão muito acima dos verificados para o Nordeste, este estado é incorporado à área de atuação da SUDENE.

92 Revista de História Regional 16(1): 61-99, Verão, 2011 
do Porto de Tubarão (1966) e a implantação de cinco usinas de pelotização de minério de ferro, entre 1969 e $1979^{51}$ consorciadas aos capitais japonês, italiano e espanhol, o que representou um crescimento significativo da indústria extrativa mineral na região. O Espírito Santo contava ainda com a entrada em operação da usina de pelotização da Samarco (1978), no municipio de Anchieta, de capital canadense, com uma moderna infraestrutura de transporte marcada pela implantação do Porto de Ubu e de um mineroduto. Esses investimentos, aliados à implantação da Aracruz Celulose (1979) e da CST $^{52}$ (1983), além das melhorias no sistema de transportes, incluindo a infraestrutura portuária, representaram o que na literatura do estado ficou conhecido pela denominação de "Grandes Projetos" e marcaram um redirecionamento da integração da economia capixaba aos mercados nacional e internacional.

Foi esse conjunto de investimentos que modificou, a partir da ação estatal, o perfil da economia capixaba, fato que seria impossivel a partir dos desdobramentos de sua cafeicultura. Não por acaso, desde os anos 1970 o estado cresce acima da média nacional. No início do século XXI, o Espírito Santo apresenta-se como uma área com dinamismo econômico superior à média nacional e fortemente integrada aos mercados nacional e internacional. São evidências dessa integração econômica com o exterior seu grau de abertura (exportações + importações/PIB estadual) de 60\%, que lhe confere a posição de economia estadual mais extrovertida entre as 27 unidades federativas. Como indicativo de sua forte integração com o mercado interno, o estado registrou uma movimentação de compras e vendas com outras unidades federativas da ordem de $75 \%$ de seu PIB (ano de $1999^{53}$ ), o maior do país.

Em seu território encontram-se importantes empresas da indústria extrativa, metalúrgica e de papel e celulose,

\footnotetext{
${ }^{51}$ Foram as seguinte usinas com seus anos respectivos de início de operação: CVRD I (1969), CVRD II (1973), ITABRASCO (1976), NIBRASCO (1978) e HISPANOBRAS (1979).

${ }^{52}$ Atual AcelorMittal.

${ }^{53}$ Último ano para qual há essa informação comparável entre as unidades federativas.
} 
todas com produção prioritariamente voltada para o mercado internacional, o que explica o caráter extrovertido de sua estrutura produtiva. Em 2009, das 50 maiores empresas exportadoras no Brasil, quatro localizam-se no

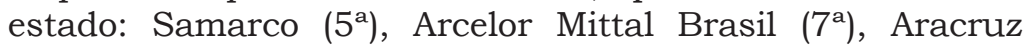
Celulose $\left(18^{\mathrm{a}}\right)$ e Flexibrás $\left(45^{\mathrm{a}}\right)$. Além delas, a Vale $\left(3^{\mathrm{a}}\right)$ tem importância crucial nas exportações capixabas pela localização do referido complexo de usinas de pelotização em Vitória, constituído hoje por sete unidades, com capacidade total de produção de 25 milhões de toneladas de pelotas/ ano. Essas empresas realizaram importantes investimentos na década de 1990, ampliando a capacidade de produção e de exportação, podendo aproveitar-se do crescimento recente da economia internacional puxado pela China. Destacamse a implantação da fábrica C pela Aracruz Celulose (2002), o laminador de tiras a quente da CST (2002) e a usina de pelotização Kobrasco (1995), joint venture entre o capital sul-coreano (50\%) e a Vale (50\%). Mais recentemente, os investimentos da indústria petrolifera elevaram suas taxas de crescimento, gerando externalidades positivas em sua base produtiva, espraiando o crescimento por uma faixa litorânea da capital até o extremo sul do estado.

Também foi fundamental para essa inserção de sua economia no mercado externo a constituição de um instrumento específico de atração de investimento - o FUNDAP ${ }^{54}$-, que contribuiu significativamente para o crescimento de sua importações. Instrumento de renúncia fiscal criado em 1970 para aumentar as operações pelo Porto de Vitória e atrair investimentos em atividades industriais quando ainda eram fortes os efeitos negativos da crise na cafeicultura, foi largamente utilizado na década de 90 do século XX, permitindo aos comerciantes locais e nacionais beneficiarem-se da abertura comercial intensificada no Brasil a partir daquela década e do aumento da "guerra fiscal" entre os estados brasileiros. Com isso, o Espírito Santo beneficiouse do referido mecanismo para ampliar sua participação no total das importações brasileiras, atraindo uma série de

${ }^{54}$ Fundo de Desenvolvimento das Atividades Portuárias.

94 Revista de História Regional 16(1): 61-99, Verão, 2011 
tradings companies que se instalaram na RMGV, aumentando sua inserção no comércio internacional. Reforçava-se, assim, o papel da capital como importante praça mercantil e terciária que vinha desde os governos Muniz Freire.

Por outro lado, a integração com a economia nacional foi incentivada pela proximidade com os maiores mercados consumidores nacionais - São Paulo, Rio de Janeiro e Minas Gerais - e pela constituição do referido sistema de incentivos que permitiu o financiamento de um conjunto de pequenas e médias empresas em segmentos de bens de consumo leves. Essas empresas escoaram suas produções para o mercado nacional, aproveitando-se tanto da maior integração do mercado nacional promovida pela industrialização brasileira pós-1950, quanto pelo aumento da urbanização que ampliou o mercado para os seus produtos.

Dessa forma, observa-se no Espírito Santo a constituição de uma economia integrada nacional e internacionalmente, mas com estrutura extremamente heterogênea, especialmente na indústria, que coloca o estado capixaba em posição peculiar na divisão inter-regional do trabalho da economia brasileira. De um lado, ele é atualmente locatário de empresas de grande porte que se articulam diretamente ao mercado externo, beneficiando-se de suas boas condições de logística apoiadas em uma grande infraestrutura ferro-rodo-portuária. ${ }^{55}$ Essas empresas têm suas lógicas de acumulação e de crescimento atreladas ao movimento da economia internacional e nas quais os atores locais pouco ou nada podem interferir. Por outro, possui um conjunto de pequenas e médias empresas integradas ao mercado interno. Destacam-se os segmentos de rochas ornamentais, de bebidas e alimentos, de confecções e de móveis. Em comum, o fato de todos terem nos estados próximos seus principais mercados. Ademais, podem ser classificados como produtores de bens-salários, portanto, dependentes de rendas das famílias e diretamente afetados pelas condições internas da economia brasileira.

${ }^{55}$ Sobre o assunto, ver: <www.transporte.gov.br>. 
Do ponto de vista espacial, observa-se uma grande concentração econômica na RMGV e o esvaziameto do interior, onde se localiza secularmente sua agricultura. Em 2005, o aglomerado metropolitano abrigava em seus sete municipios $47,3 \%$ da população residente no estado, ficando os demais 71 municípios com o restante. Do ponto de vista econômico, a RMGV respondia por $64,1 \%$ do PIB estadual e apresentava um PIB per capita de praticamente o dobro do interior do estado.

Neste início de século XXI no Espírito Santo, poucos resquícios restam de seu passado cafeeiro.

\section{Considerações finais}

$\mathrm{Na}$ primeira metade do século XIX, os territórios da provincia do Espírito Santo apresentavam uma estrutura específica resultante de determinações relacionadas à própria inserção da economia brasileira durante o período colonial. À margem dos principais centros de produção e comercialização, essas áreas permaneceram com esparso povoamento e precária ocupação econômica.

Contudo, o advento, ainda que relativamente tardio, da economia cafeeira trouxe à região novas possibilidades de desenvolvimento. Neste artigo, procurou-se mostrar como a dinâmica da economia cafeeira em pequenas propriedades, apesar de conter em germe as possibilidades de mudança qualitativa do Espírito Santo, não logrou êxito em modernizar essa sociedade em direção a uma base urbana e industrial.

Seria descuidado, todavia, não explicitar passos importantes, como a constituição de núcleos urbanos pelo interior - estruturando a rede urbana capixaba - e a consolidação de Vitória como a principal e a mais importante cidade espírito-santense. Nessa cidade assistiu-se ao processo de diversificação das atividades do setor terciário, que lhe am- 
pliou a centralidade a partir do movimento do seu porto, cujo sucesso esteve pautado nos ganhos de escala advindos dos investimentos realizados no início do século XX e que possibilitaram ao Espírito Santo centralizar a comercialização do café produzido em seu território.

Sem dúvidas, resta ainda por realizar um estudo mais pormenorizado do desenvolvimento da cafeicultura capixaba no período entre a segunda metade do século XIX e a primeira metade do século XX em um sentido positivo. Conforme indicado neste trabalho, já existem referências a respeito da não satisfação de condições necessárias para o crescimento industrial e urbano pela economia espírito-santense, baseados em metodologias comparativas com centros de maior dinamismo na economia brasileira. No entanto, ainda há carência de pesquisas que possam caracterizar positivamente o desenvolvimento dessa agricultura de pequenas propriedades no Espírito Santo, especialmente detalhando suas relações mercantis com os espaços vizinhos.

Ainda segundo as ideias aqui apresentadas, a segunda metade do século XX é um ponto de inflexão e fundamental para uma reavaliação da dinâmica do estado. Os grandes projetos industriais surgiram como alternativa frente ao esgotamento do café, mas, novamente, são decorrências de fatores ligados a estratégias e movimentos históricos que extrapolam sua dinâmica própria. Apesar da ampliação de sua infraestrutura e de sua rede urbana, o principal movimento dinamizador socioeconômico e conformador espacial é fruto da instalação de empresas estatais e toda uma estrutura com foco no comércio exterior. ${ }^{56}$

As últimas décadas têm assistido a um amplo debate sobre a necessidade de criar mecanismos para a diversificação e dinamização da economia local. Necessariamente qualquer estudo sobre essa realidade deverá abarcar o alto grau de

\footnotetext{
${ }^{56}$ Não é prudente negligenciar o fato de que entre alguns estudiosos da realidade espírito-santense apareça a tese de que o estado possui uma "inclinação natural" ao comércio exterior, embora, como visto, trate-se de um processo com profundas raizes históricas.
} 
extroversão da economia capixaba, fruto da especificidade de seu desenvolvimento histórico.

Resumo: O estado capixaba apresenta o maior grau de abertura econômica do Brasil, sustentada por uma infraestrutura portuária correlacionada a uma base produtiva extremamente extrovertida. Resultado de múltiplas determinações que, ao longo dos últimos 150 anos, atuaram sobre essa pequena fração do território brasileiro, a economia capixaba, no entanto, esteve assentada, até meados do século XX, em pequenas propriedades produtoras de café cuja produção era comercializada a partir da cidade de Vitória. Seu porto permitiu-1he a centralização do café produzido nas distintas regiões estaduais, criando externalidades que puderam ser apropriadas na capital quando a indústria começa a se desenvolver, influenciada tanto pela atuação da Companhia Vale do Rio Doce, a partir de 1942, quanto pelo sistema de incentivos fiscais criado na década de 1960. Este artigo busca reconstituir a trajetória da economia capixaba entre 1847 e 2010. O ano de 1847 é o ponto de partida porque marca o início da colonização estrangeira no estado e, portanto, da cafeicultura em pequenas propriedades que determinou a dinâmica de sua economia até a década de 1950. Essa colonização retirou o Espírito Santo da condição de relativo isolamento em relação ao resto do território brasileiro e lançou as bases para seu desenvolvimento posterior.

Palavras-chave: Espírito Santo. História Regional. Desenvolvimento Regional.

Abstract: Espírito Santo presents the highest level of economic openness among all states in Brazil, sustained by a portuary infrastructure relationed to extremely extroverted productive system. Result of multiple determinations that for the last 150 years have affected this little part of the brazilian territory, Espirito Santo's economy, however, was based, until the middle of the twentieth century, on small coffee properties whose production was commercialized from the capital city of Vitória. Its port has allowed the centralization of all the coffee produced in the different regions of the state, 
what had generated externalities that could be appropriated in the capital port when the industry has begun to arise influentiated by the activities of Companhia Vale do Rio Doce (since 1942) and by a system of fiscal incentives created in the $1960^{\circ}$ s. This issue major objective is to reconstitute the Espirito Santo economic trajectory between 1847 and 2010. 1847 is the start point because it marks the beginning of the foreign colonization process in the state and, that way, of the coffee production in small properties that has determined its economic dynamics until the 1950`s. This process of colonization moved Espírito Santo from a condition of relative isolation and has generated the bases for its further development.

Keywords: Espírito Santo; Regional History; Regional Development.

Artigo recebido para publicação em 29/01/2010

Artigo aprovado para publicação em 25/04/2011 